\title{
Kobe earthquake shatters faith in engineers
}

Tokyo. The collapse of multi-storey buildings, and the rupture of highways and railway lines in the earthquake in Kobe has stunned the Japanese public and left civil engineers with the embarrassing task of explaining why their designs failed to stand up to the earthquake.

The collapse of the highways in particular has caused major disruption both to the relief effort and to supply routes for industry throughout the region. Officials of the Construction Ministry continue to insist that the $250 \mathrm{~km}$ of expressway in Tokyo will stand up to the equivalent of the Great Kanto Earthquake of 1923 which measured 7.9 on the Richter scale. But many sections of the expressway in Tokyo are even older than that which failed in Kobe and have a similar design.

As the dust clears, it is evident that much of the structural failure can be traced to old, less-stringent building codes that applied before 1980. But some modern buildings also failed. On the bright side, the many new multi-storey buildings on Kobe's manmade Port Island stood up to the earthquake, despite extensive liquefaction of the reclaimed land on which they stand.

A year ago, when the Northridge earthquake levelled highways in Los Angeles in the United States, Japanese civil engineers who visited the disaster site returned home and confidently reassured the Japanese public that Japan's highways were built to higher standards and could withstand such an earthquake. Yet although the ground motions that shook Kobe were probably no stronger than those that occured at Northridge (see below), the Hanshin expressway, a major artery of Japan's road system, collapsed in several places.

"I am shocked," said Manabu Ito, a civil engineer at Saitama University, on TV Asahi the morning after the earthquake as he looked at television pictures of a 600 -metre section of the Hanshin expressway that had toppled on its side (see right). "I could not imagine this would happen".

But George Housner, professor of engineering at the California Institute of Technology and an expert in earthquake engineering, says that he is not surprised by the highway's collapse. The highway was built 25 years ago and did not incorporate modern principles of ductile design, pioneered in California in the 1970 s but not brought into Japanese building codes until 1980 .

Inspection at the site by civil engineers tends to bear out Housner's view. The highway's vertical support pillars, which sheared, are made of concrete and have vertical reinforcement rods running through them that are supported by horizontal hoops. Under the old building code, the hoops were spaced at intervals of about $30 \mathrm{~cm}$. But under the new code they have to be every $10 \mathrm{~cm}$.

Many of the multi-storey buildings in Kobe that collapsed were made of reinforced concrete with the same large spacing of hoops, suggesting this is a factor in their collapse. But one or two more modern buildings with $10-\mathrm{cm}$ spaced reinforcing have also collapsed.

Another factor is that the highway on top of the support pillars in the long section that failed is made of reinforced concrete. The immediately adjacent section made of steel did not collapse. The reinforced concrete weighs twice as much as the steel, creating a top-heavy structure that put enormous strain on the vertical pillars when subjected to the strong horizontal forces of the earthquake. Steel sections of the highway elsewhere also collapsed, but not so extensively,

\section{Striking similarities with US quake}

Tokyo. The way that the ground shook during last week's Kobe earthquake ap pears to have been similar to that which took place during the earthquake under Northridge in Los Angeles exactly one year earlier - on 17 January 1993 - according to preliminary data from Japanese researchers.

Both earthquakes were relatively shallow, and occurred off the main plate boundary, under heavily urbanized areas. The Kobe earthquake was of greater magnitude ( 7.2 on the Richter scale) as opposed to 6.6 for Northridge. But, unlike Northridge, the earthquake was not centred directly under Kobe but about $20 \mathrm{~km}$ to the southwest, under Awaji island.

A network of 10 seismometers in the Kobe-Osaka region set up by Kenzo Toki of
Kyoto University in April 1994 recorded maximum ground velocities of $30-55$ $\mathrm{cm} \mathrm{s}^{-1}$ along the fault zone that ruptured. This compares with a maximum of 170 $\mathrm{cm} \mathrm{s}^{-1}$ at Northridge.

But two of Toki's meters in the centre of the earthquake zone went off the scale at $40 \mathrm{~cm} \mathrm{~s}^{-1}$ as they had been set at higher sensitivity. Furthermore, according to Toki, a seismometer operated by Osaka Gas Company in central Kobe also went off its scale at $99.9 \mathrm{~cm} \mathrm{~s}^{-1}$. This indicates that the maximum velocity was at least $100 \mathrm{~cm} \mathrm{~s}^{-1}$.

The peak acceleration of $818 \mathrm{~cm} \mathrm{~s}^{-2}$ (almost equal to the acceleration of gravity) in a north-south direction, reported by the Japan Meteorological Agency, is similar to the maximum recorded in Northridge.D. S.
Two-pillar construction may have avoided Hanchin expressway collapse.

and only at joints.

Tsutomu Kimura, a civil engineer and president of the Tokyo Institute of Technology, says there is an inherent weakness in the T-shaped support pillars because the single pillars have "no redundancy". If one pillar fails, the whole highway on top collapses.

A two-pillar structure would be safer, but Japan has opted for the one-pillar design in many places because of lack of space, because highways usually have to be built over existing roads, and because prohibitively high land prices prevent the government from buying up the necessary land for double supports.

Moves to reinforce the T-shaped pillars with steel casing have been going on for several years. But fewer than half of the hundreds of pillars in the Tokyo and Osaka-Kobe region that need reinforcement have been treated because of budgetary constraints.

Kobe has large tracts of reclaimed land along its waterfront, but this does not appear to have been a factor in the collapse of the highways, according to Kenzo Toki, a civil engineer from Kyoto University who has visited the disaster site.

In fact, the many multistorey buildings on Port Island withstood the shock, despite liquefaction of the underlying reclaimed land, because the buildings have pillars in their foundations extending to a depth of more than 30 metres to root them into solid ground underlying the reclaimed layer.

However, one tank for liquefied gas on reclaimed land in Kobe port did rupture, probably due to subsidence, and thousands of nearby residents had to be evacuated. Such tanks are another major concern in Tokyo because there are hundreds of them for petroleum, gas and chemicals, rimming Tokyo Bay on recently reclaimed land.

David Swinbanks 